\title{
Insulin Receptor Binding and Receptor-Mediated Insulin Degradation in Human Adipocytes
}

\author{
O. Pedersen, E. Hjøllund, H. Beck-Nielsen, H. O. Lindskov, O. Sonne, and J. Gliemann \\ Division of Endocrinology and Metabolism, Department of Internal Medicine and Department of Clinical Chemistry, \\ County Hospital, Aarhus, and Institute of Physiology, University of Aarhus, Denmark
}

\begin{abstract}
Summary. ${ }^{125} \mathrm{I}$-insulin binding and receptor-mediated insulin degradation were studied in isolated human fat cells from subcutaneous tissue. A high albumin concentration during cell isolation and incubation protected the fragile human adipocyte from lysis. Binding of tracer was $\mathrm{pH}$ dependent with an optimum between 7.4 and 7.6. At $37^{\circ} \mathrm{C}$ steady state was reached by $45 \mathrm{~min}$ and maintained for at least $2 \mathrm{~h}$. The binding of labelled insulin in the presence of $10 \mu \mathrm{mol} / 1$ unlabelled insulin was only $1-4 \%$ of the total insulin binding. The half-maximal displacement of tracer iodoinsulin $(10 \mathrm{pmol} / \mathrm{l})$ by unlabelled insulin occurred at $0.25 \mathrm{nmol} / \mathrm{l}$. Kinetic studies of the dissociation of labelled iodoinsulin from fat cells showed a slight acceleration in the presence of a high concentration of unlabelled insulin in the washout buffer as compared to a buffer containing no insulin. At steady state binding about $95 \%$ of the cell-associated radioactivity was extracted as iodoinsulin as judged by gel filtration. The remaining $5 \%$ co-eluted with iodotyrosine. During $60 \mathrm{~min}$ about $90 \%$ of the cellassociated radioactivity dissociated as iodoinsulin and the rest as iodotyrosine. Conclusions: 1) A high albumin content of buffers prevents traumatization of the human adipocyte; 2) under these conditions steady state binding of insulin is readily measured at $\left.37^{\circ} \mathrm{C} ; 3\right)$ the use of a washing procedure makes the non-specific binding negligible; 4) the human adipocyte insulin receptor has a very high affinity; 5) receptor-mediated insulin degradation is minimal.
\end{abstract}

Key words: Insulin, insulin receptors, insulin degradation, human adipocytes

Studies of insulin binding to human adipocytes were carried out for the first time several years ago by Olefsky et al. [1]. They evoked great interest, fol- lowed by other investigations from several other groups. However, it has been obvious ever since the first investigations that great technical problems had to be solved before a suitable method for use on a larger scale for clinical research could be elaborated. In the first study [1] a steady state of insulin binding was unattainable at $37^{\circ} \mathrm{C}$. Subsequent studies were therefore carried out at a lower temperature and binding was measured after 10-45 min [2-4]. By this time maximum binding but not necessarily steady state may have been attained for a given population of adipocytes. Andersen et al. [5] showed that steady state binding could be established in human omental fat cells at $37^{\circ} \mathrm{C}$. However, nonspecific binding accounted for about thirty per cent of the total binding in these studies [5] and the technique was consequently not suited for detailed kinetic experiments or for clinical studies. Receptor-mediated insulin degradation has been described in rat adipocytes $[6,7]$ but this phenomenon has never been studied in human fat cells. To provide a basis for clinical studies of the interrelationship between insulin receptor binding, receptor-mediated insulin degradation and insulin action in human fat cells from subcutaneous tissue we have 1) defined the experimental conditions for isolation and incubation of human fat cells in order to ensure the maintenance of a steady state binding at $37^{\circ} \mathrm{C}$; 2) minimized nonspecific insulin binding; 3 ) investigated the kinetics of insulin binding and receptor-mediated insulin degradation at $37^{\circ} \mathrm{C}$ and pH 7.4.

\section{Material and Methods}

\section{Chemicals}

Human albumin: Behringwerke, Marburg, FRG. Collagenase from Clostridium Histolyticum, No C-2139, lot $107 \mathrm{C}-6800,185$ units/mg: Sigma, St. Louis, USA. Porcine insulin and glucagon: 


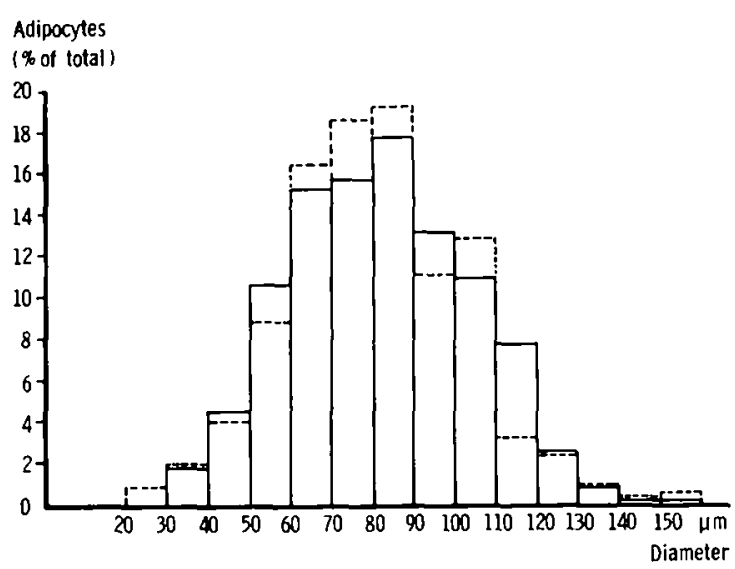

Fig. 1. Histograms for cell diameter distribution in isolated fat cells and in frozen-cut adipose tissue. Adipose tissue was obtained from 10 subjects. A piece of tissuc was frozen-cut after fixation with $35 \% \mathrm{w} / \mathrm{v}$ formaldehyde and the diameter of 200 cells was measured from each biopsy (------). Adipocytes were collagenase isolated and the diameter of 200 cells was measured from each preparation (- - ). The mean diameter of 2,000 cells in adipose tissue was $79 \mu \mathrm{m}$, whereas that in preparations of isolated cells was $80 \mu \mathrm{m}$

Novo Research Institute, Copenhagen, Denmark. ${ }^{125}$ I-monoiodoinsulin with the labelled iodine in tyrosine $\mathrm{A}_{14}$ (specific activity $200-250 \mu \mathrm{Ci} / \mu \mathrm{g})$ and ${ }^{125} \mathrm{I}$-monoiodoinsulin with the labelled iodine in tyrosine $A_{19}$ (specific activity $150-175 \mu \mathrm{Ci} / \mu \mathrm{g}$ ): gifts generously donated by the Novo Research Institute, Copenhagen, Denmark [8]. In all receptor studics except for a comparison between binding of $A_{14}$ and $A_{19}$ monoiodoinsulin, $A_{14}$ monoiodoinsulin was used. Silicone oil No $510 / 50$ (relative density 0.99 , viscosity 100 centistokes): Dow Corning Cooperation, Midland, Michigan, USA. L-1- ${ }^{14} \mathrm{C}$-glucose (specific activity $61 \mathrm{mCi} / \mathrm{mmol}$ ): Radiochemical Centre, Amersham, England. Tissuc and cells werc suspended in buffer containing the following substance concentrations in $\mathrm{mmol} / \mathrm{l}: \mathrm{NaCl} 135, \mathrm{KCl} 4.8, \mathrm{MgSO}_{4} 1.70, \mathrm{CaCl}_{2}, 2.5$, $\mathrm{NaH}_{2} \mathrm{PO}_{4} 1.0$ and 4-(2-hydroxyethyl)-1-piperazine ethanesulfonic acid (Hepes) $10 ; \mathrm{pH}$ was adjusted to 7.4 at $37^{\circ} \mathrm{C}$ with $1 \mathrm{~mol} / \mathrm{l}$ $\mathrm{NaOH}$, unless indicated otherwise. During incubation of fat cells for $60 \mathrm{~min}$ at $37^{\circ} \mathrm{C}$ at a final volume fraction of $0.05, \mathrm{pH}$ of medium dropped less than 0.1 from the original $\mathrm{pH}$. Human albumin was present at $10-50 \mathrm{mg} / \mathrm{ml}$.

\section{Subjects}

Specimens of subcutaneous adipose tissue were obtained from the abdomen of 35 females and 20 males undergoing gynecological or gastroenterological surgery (sterilisation or duodenal ulcer). The patients were from 20 to 70 years old and their relative body weight was $\pm 15 \%$ of ideal weight [9]. None of the donors suffered from endocrine disorders. The subjects were fasted for about $12 \mathrm{~h}$ overnight. Preoperative medication was diacepam and atropine. General anaesthesia was induced with a short-acting barbiturate and maintained with halothane, nitrous oxide and oxygen.

\section{Preparation of adipocytes}

The tissue specimen was excised at the beginning of the operation and placed in a $37^{\circ} \mathrm{C}$ warm saline $(154 \mathrm{mmol} / 1)$-glucose $(5 \mathrm{mmol} /$ l) medium. The tissue was brought to the laboratory in a vacuum jug within $15 \mathrm{~min}$. The tissue was cut into fragments weighing 20-30 mg with care to remove obvious connective tissue and clotted blood. The minced fragments were washed three times in $37^{\circ} \mathrm{C}$ warm saline-glucose medium and collected in polyethylene tubes with about $1 \mathrm{~g}$ of tissue and $2 \mathrm{ml}$ of Hepes buffer (supplemented with $25 \mathrm{mg} / \mathrm{ml}$ human albumin and $5 \mathrm{mmol} / \mathrm{l}$ glucose) in cach tube. Crude collagenase was added to a final concentration of $0.5 \mathrm{mg} /$ $\mathrm{ml}$. The tubes were then shaken (about $100 \mathrm{cycles} / \mathrm{min}$ ) at $37^{\circ} \mathrm{C}$ for $60 \mathrm{~min}$. The remaining stroma containing some fat cells was then removed and the cell suspension was filtered through two layers of gauze and one layer of a nylon mesh with an aperture diameter of $250 \mu \mathrm{m}$. This filtration procedure was repeated and the cells were allowed to float. The infranatant was removed by suction and the adipocytes were transferred to a polypropylene tube. The preparation of fat cells was washed four times by centrifugation at $5 \mathrm{~g}$ for $1 \mathrm{~min}$ in a volume of $5 \mathrm{ml}$ of albumin enriched Hepes buffer $(50 \mathrm{mg} / \mathrm{ml}$ human albumin). After the final rinse the adipocytes were resuspended in the incubation buffer $(50 \mathrm{mg} / \mathrm{ml}$ human albumin and $5 \mathrm{mmol} / 1$ glucose) and concentrated by centrifugation at $5 \mathrm{~g}$ for $1 \mathrm{~min}$. The volume fraction of adipocytes was measured in duplicate by filling a haematocrit capillary tube with a sample of the fat cell suspension. After centrifugation at $13.400 \mathrm{~g}$ for $3 \mathrm{~min}$ in a haematocrit centrifuge the ratio of volume occupied by the packed cells to the total volume was determined. This measurement had a coefficient of variation of $0.024(n=25)$ at volume fractions of about 0.40 .

\section{Fat Cell Diameter, Viability and Cell Number Concentration}

To measure fat cell size, the cell suspension was diluted in buffer to about $4 \times 10^{4}$ cells $/ \mathrm{ml}$. With an automatic pipettc held vertically with the tip pointing upwards a 5-ul sample was placed on the grid of a Fuchs-Rosenthal cell counting chamber turned upside down. The diameter of the whole cell population was measured at $200-$ fold magnification using a eyepiece micrometer. Surface area $\left(\pi D^{2}\right)$ and volume $\left(\pi D^{3} / 6\right)$ were calculated for every measured cell diamcter assuming that the fat cell has the shape of a ball. The precision of the sizing procedure was evaluated by repeating the measurement of diameter in five replicate 200 adipocyte samples from the same cell batch. The coefficient of variation was 0.015 . Adipocyte viability was examined by fluoroscence microscopy in acridine orange $(0.1 \% \mathrm{w} / \mathrm{v})$ stained cell preparations [10]. Cell viability was higher than $97 \%$.

Fat cell diameter in frozen-cut and formaldehyde-fixed adipose tissue was estimated using the technique described by Sjöström et al. [11]. The concentration of cells in adipocyte suspensions was calculated as adipocyte volume fraction divided by mean adipocyte volume. The mean adipocyte volume was obtained from the individually calculated cell volumes.

\section{Evaluation of Methods for Preparation of Human Fat Cells}

The cell diameter distributions (Fig. 1) of collagenase isolated fat cells and fat cclls of adipose tissue were almost identical, indicating that no major selection of cells occurred during treatment with collagenasc and during the washing procedure. A series of experiments showed that the concentrations of albumin and collagenase in the buffer during cell isolation must be balanced to prevent breakage of cells and to maximize the yield of fat colls. With the chosen batch of collagenase we obtained a constant yield $(0.37 \pm 0.10 \mathrm{~g}$ packed cells from $1 \mathrm{~g}$ of adipose tissue) and practically no evidence of cell lysis when adipose tissue was incubated with collagenase at four different concentrations from 0.5 to 
$3.0 \mathrm{mg} / \mathrm{ml}$ in a buffer with a fixed concentration of human albumin $(25 \mathrm{mg} / \mathrm{ml} ; \mathrm{n}=5)$. This albumin concentration had been found optimal with the given concentrations of collagenase. The adipocyte insulin binding and receptor-mediated insulin degradation were both independent on the amount of collagenase which was used for cell isolation (data not shown). A crucial point in the preparation and use of human fat cells was the albumin concentration of buffer during the washing procedure and subsequent incubation. Comparative studies on the effect of $10 \mathrm{mg} / \mathrm{ml}$ albumin versus $50 \mathrm{mg} / \mathrm{ml}$ in buffer showed an adipocyte protective effect of albumin. In five individual experiments in which the diameter of 1000 cells from each buffer preparation were measured before and after cell wash and again after incubation for $60 \mathrm{~min}$ at $37^{\circ} \mathrm{C}$ showed an unchanged distribution of cell diameters when cells were prepared and incubated in buffers with $50 \mathrm{mg} / \mathrm{ml}$ albumin whereas the contribution of cells with diameters above $100 \mu \mathrm{m}$ was reduced by $21 \pm 5 \%(p<0.05)$ after washing and incubation in buffers containing $10 \mathrm{mg} / \mathrm{ml}$ albumin. This protective effect of albumin was substantiated by the finding that specific binding at insulin tracer concentration to large adipocytes $(92 \pm 14 \mu \mathrm{m})$, washed and incubated at $37^{\circ} \mathrm{C}$ for $60 \mathrm{~min}$ in buffers with $10 \mathrm{mg} / \mathrm{ml}$ of albumin was $20 \pm 3 \%$ lower $(p<0.01)$ than the binding in presence of $50 \mathrm{mg} / \mathrm{ml}$ albumin (11 separate experiments in which the concentration of ionized calcium and magnesium was kept constant at 1.25 and $0.5 \mathrm{mmol} / 1$, respectively). This reduction in insulin binding could not be ascribed to changes in insulin degradation.

\section{Insulin Binding Studies}

Concentrated cell suspensions were diluted in buffer containing $50 \mathrm{mg} / \mathrm{ml}$ human albumin to a final volume fraction of adipocytes ranging from 0.05 to $0.10 .25 \mu \mathrm{l}$ of tracer $\mathrm{A}_{14^{-}}{ }^{125}$-I-monoiodoinsulin and $25 \mu \mathrm{l}$ of unlabelled insulin (as indicated in legends to Figs.) or buffer were added to $200 \mu \mathrm{l}$ cell suspension. Incubations were carried out at $37^{\circ} \mathrm{C}$ or $20^{\circ} \mathrm{C}$ in a shaking water bath (about 100 cycles/min). The incubations were terminated by the addition of $9.75 \mathrm{ml}$ chilled $\left(4^{\circ} \mathrm{C}\right) 0.154 \mathrm{~mol} / \mathrm{l}$ saline followed by $1.2 \mathrm{ml}$ chilled silicone oil [6]. After centrifugation for $1 \mathrm{~min}$ at about $2,500 \times \mathrm{g}$ at $4{ }^{\circ} \mathrm{C}$ the cells were layered on the top of the oil and sucked into the tip of a disposable pipette or adsorbed to a bit of a pipe cleaner. Both cell bound and free radioactivity was counted. Total cell binding indicates the radioactivity of the cells. Nonspecific cell binding is radioactivity of the cells in the presence of an excess of unlabelled insulin $(10 \mu \mathrm{mol} / \mathrm{l})$. Specific cell binding is defined as the difference between the total and the nonspecific binding and expressed as a fraction of the total radioactivity. All binding studies were done using duplicate incubations. The coefficient of variation for determination of total insulin binding fraction was 0.030 and that for nonspecific binding fraction was 0.101 ( $\mathrm{n}=25$ consecutive studies). The precision of the measurement of the specific adipocyte binding fraction at insulin tracer concentration was 0.031 . The fraction of iodoinsulin trapped extracellulary after separation of cell bound and free insulin was determined by L-1${ }^{14} \mathrm{C}$-glucose $(0.8 \mu \mathrm{Ci} / \mathrm{ml})$ incubation for $1 \mathrm{~min}$.

\section{Insulin Degradation Studies}

In all studies of insulin degradation adipocytes at a volume fraction at 0.10 were incubated in duplicate with $\mathrm{A}_{14}$-iodoinsulin (final concentration $140 \mathrm{pmol} / \mathrm{l}$ ) for $60 \mathrm{~min}$ at $37^{\circ} \mathrm{C}$.

The nature of the bound radioactivity taken up by adipocytes after $1 \mathrm{~h}$ was analysed by gel filtration on a column $(1.5 \times 90 \mathrm{~cm})$ Sephadex $\mathrm{G}-50$ fine eluted at $4{ }^{\circ} \mathrm{C}$ with $1 \mathrm{mg} / \mathrm{ml}$ albumin in $0.5 \mathrm{~mol} / 1$ acetic acid after extraction of the cell pellet for $60 \mathrm{~min}$ at $4{ }^{\circ} \mathrm{C}$ in a mixture of acetic acid $(3 \mathrm{~mol} / \mathrm{l})$ and urea $(6 \mathrm{~mol} / 1)$ [6].
The degradation of iodoinsulin in the incubation medium after incubation of adipocytes for $1 \mathrm{~h}$ was measured by its solubility in $12 \% \mathrm{w} / \mathrm{v}$ trichloroacetic acid (TCA).

When studying the degradation of receptor-bound insulin cells were incubated for $1 \mathrm{~h}$ at $37^{\circ} \mathrm{C}$ in the presence of ${ }^{125} \mathrm{I}$-insulin, removed from the infranatant after centrifugation through silicone oil at $4{ }^{\circ} \mathrm{C}$ and incubated in $1 \mathrm{ml}$ buffer $(50 \mathrm{mg} / \mathrm{ml}$ human albumin) at $37^{\circ} \mathrm{C}$ for another $60 \mathrm{~min}$. A sample of the medium was then isolated for analysis of insulin degradation after removal of the cells by centrifugation through silicone oil. Under these conditions total degradation of the bound tracer insulin was measured. In other studies the extracellular degradation of tracer was inhibited by adding unlabelled insulin $(10 \mu \mathrm{mol} / \mathrm{l})$ to the washout buffer. The degradation of iodoinsulin was measured by 1) its solubility in TCA and 2) by gel filtration. All insulin degradation studies were done in duplicate. The coefficient of variation for determination of receptor-mediated insulin degradation after $60 \mathrm{~min}$ using the TCA-method was 0.088 ( $\mathrm{n}=25$ consecutive experiments).

\section{Statistical methods}

Results are presented as mean \pm 1 SD. In Figs. $2-4$ data are given as mean \pm 1 SEM. Student's t-test was used to test paired observations. Linear regression analysis was employed in correlation studies using the least-squares method. The number of samples (n) equals the number of persons.

\section{Results}

\section{Dependence of Adipocyte Binding on ${ }^{125}$ I-Insulin Tracer, Cell Number Concentration and $\mathrm{pH}$}

The specifically bound fraction at insulin tracer concentration $(10 \mathrm{pmol} / \mathrm{l})$ to adipocytes (at a final volume fraction of 0.10 ) was $5.86 \pm 1.15 \times 10^{-2}$ when monoiodoinsulin with iodine in tyrosine $\mathrm{A}_{14}$ was the tracer, whereas the specifically insulin-bound fraction was $3.01 \pm 0.89 \times 10^{-2}$ when monoiodoinsulin with iodine in tyrosine $A_{19}$ was the tracer $(n=3)$. This finding accords with similar studies in rat adipocytes $[8,12]$. The insulin binding to adipocytes at insulin tracer concentration $(10 \mathrm{pmol} / 1)$ was proportional to the cell number concentration in the range $1.0 \times 10^{5}$ to $1.5 \times 10^{6} \mathrm{cells} / \mathrm{ml}(r=0.988,0.997$, $0.985, n=3$ ). $\mathrm{pH}$ optimum for the binding of insulin to adipocytes was between 7.4 and 7.6 (Fig. 2). The following studies were carried out with $\mathrm{A}_{14}$-labelled iodoinsulin, with 1.5 to $3.5 \times 10^{5}$ cells $/ \mathrm{ml}$ and at $\mathrm{pH}$ 7.4.

\section{Insulin Binding as a Function of Time and Temperature}

Figure 3 shows the binding of tracer insulin $\left(\mathrm{A}_{14^{-}}\right.$ ${ }^{125}$-I-monoiodoinsulin, $20 \mathrm{pmol} / \mathrm{l}$ ), tracer insulin plus $1.0 \mathrm{nmol} / 1$ of unlabelled insulin and tracer insulin plus $10 \mu \mathrm{mol} / 1$ of unlabelled insulin (nonspecific binding) as functions of time at $37^{\circ} \mathrm{C}$. Steady-state of 


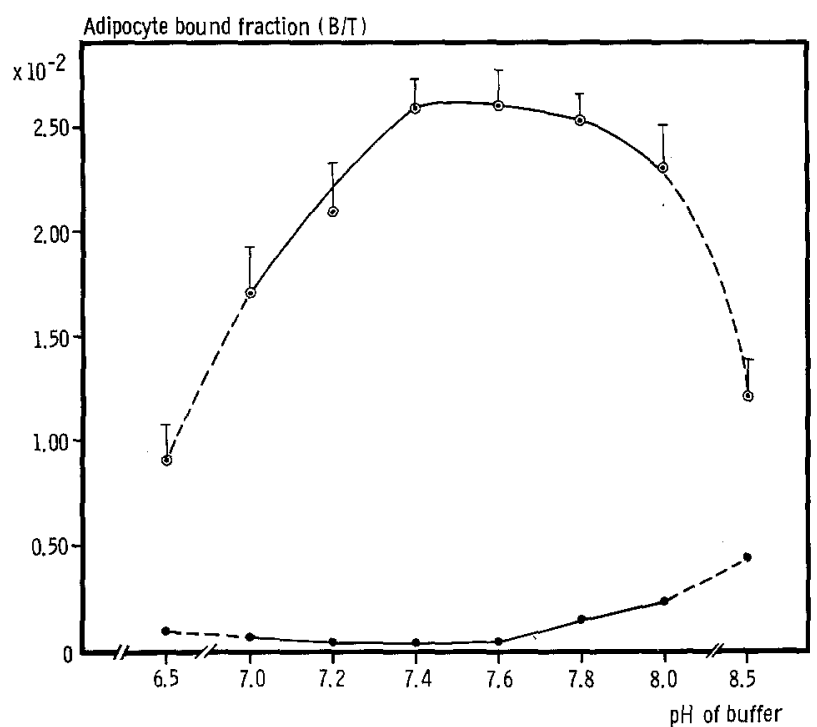

Fig. 2. ${ }^{125} \mathrm{I}$-insulin binding as a function of $\mathrm{pH}$. Adipocytes at a final volume fraction of 0.05 were incubated at $37^{\circ} \mathrm{C}$ for $60 \mathrm{~min}$ with tracer iodoinsulin $(20 \mathrm{pmol} / 1, \odot-\odot)$ alone and with tracer insulin plus $10 \mu \mathrm{mol} / \mathrm{l}$ of unlabelled insulin (-) at the buffer $\mathrm{pH}$-values. Mean values \pm 1 SEM of three separate experiments

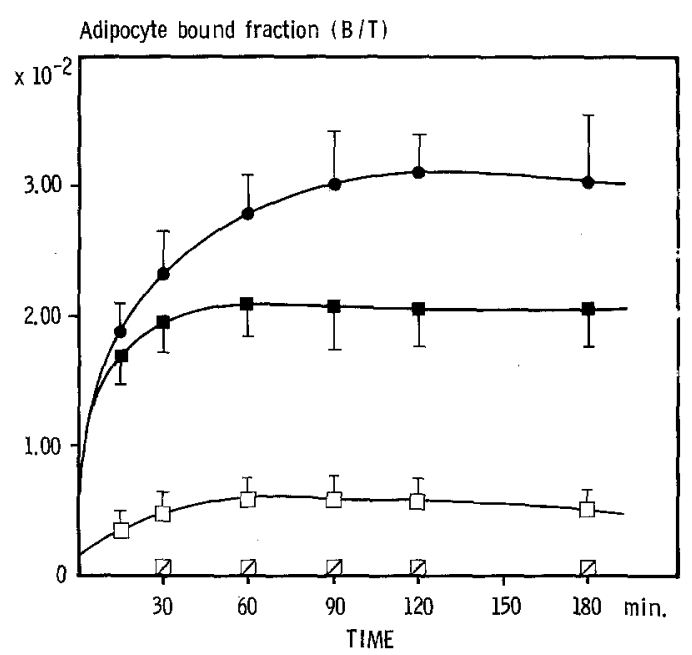

Fig. 3. Effects of time, temperature and insulin occupancy on the binding of ${ }^{125} \mathrm{I}$-insulin to human adipocytes. Adipocytes at a final volume fraction of 0.05 were incubated at $20^{\circ} \mathrm{C}(-)$ ) or at $37^{\circ} \mathrm{C}$ with tracer iodoinsulin $(20 \mathrm{pmol} / 1)(\mathbf{-})$, with tracer insulin plus $1.0 \mathrm{nmol} / \mathrm{l}$ unlabelled insulin $(\square-\square)$ and with tracer insulin plus $10 \mu \mathrm{mol} / 1$ unlabelled insulin $(\square-\square)$. The $\mathrm{pH}$ of incubation buffers was adjusted to 7.4 both at $20^{\circ} \mathrm{C}$ and $37^{\circ} \mathrm{C}$. Under these conditions insulin degradation in the medium was less than $1 \%$ after incubation for $60 \mathrm{~min}$. Mean values $\pm 1 \mathrm{SEM}$ of three separate experiments

binding was obtained after about $45 \mathrm{~min}$ and maintained for at least $2 \mathrm{~h}$ even at high occupancy. This shows that no "down regulation" of receptors occurs over this period under these conditions. Nonspecific binding was minimized to $1-4 \%$ of total binding at insulin tracer concentration. To estimate the contribution of extracellulary trapped ${ }^{125} \mathrm{I}$-insulin to the amount of nonspecifically bound insulin the ${ }^{14} \mathrm{C}$ - Lglucose distribution space was measured. About $10 \%$ of nonspecifically bound ${ }^{125} \mathrm{I}$-insulin was attributable to extracellularly trapped radioactivity. At $20^{\circ} \mathrm{C}$ insulin binding at insulin tracer concentration reached a steady state after about 90 min (Fig. 3). The binding plateau was about $50 \%$ higher than that at $37^{\circ} \mathrm{C}$. The nonspecific binding was independent of temperature. In three separate experiments (not shown) cells were incubated for $100 \mathrm{~min}$ with $20 \mathrm{pmol} / 1{ }^{125} \mathrm{I}$-insulin at $37^{\circ} \mathrm{C}$ or $20^{\circ} \mathrm{C}$ and the apparent half times of dissociation were determined by the addition of unlabelled insulin at a final concentration of $10 \mu \mathrm{mol} / 1$ as $5 \pm 1 \mathrm{~min}$ at $37^{\circ} \mathrm{C}$ and $17 \pm$ 4 min at $20^{\circ} \mathrm{C}$. Thus, the increased binding of tracer iodoinsulin at $20^{\circ} \mathrm{C}$ is probably mainly due to an increased affinity caused by a decreased dissociation rate constant, although the possible contribution of other factors (temperature effect on degree of negative cooperativity, association rate constant and number of receptors) were not explored.

\section{Insulin Binding at Equilibrium and Kinetic of Binding}

Figure 4 depicts the inhibitory effect of unlabelled porcine insulin on the ${ }^{125} \mathrm{I}$-insulin binding after $60 \mathrm{~min}$ of incubation at $37^{\circ} \mathrm{C}$. The concentration of unlabelled insulin necessary to reduce the specifically bound fraction of iodoinsulin at insulin tracer concentration $50 \%$ was about $0.25 \mathrm{nmol} / \mathrm{l}$. The corresponding Scatchard plot (inset Fig. 4) was curvilinear with an upward concavity. Proinsulin had an inhibitory effect of $0.5 \%$ of that of insulin, and glucagon inhibited insulin binding very slightly (less than 0.01 per thousand of that of insulin), presumably due to slight contamination with insulin $(n=3)$. In kinetic studies of the dissociation of bound ${ }^{125}$ I-insulin, adipocytes at a final volume fraction of 0.10 were incubated in quadruplicate of $250 \mu 1$ at $37^{\circ} \mathrm{C}$ for $60 \mathrm{~min}$ with $140 \mathrm{pmol} / 1$ of ${ }^{125} \mathrm{I}$-insulin. After wash and recovery of cells at $4{ }^{\circ} \mathrm{C}$ the adipocytes were resuspended in polyethylene tubes containing $9 \mathrm{ml}$ of Hepes buffer ( $50 \mathrm{mg} / \mathrm{ml}$ albumin). Unlabelled insulin at a final concentration of $100 \mathrm{nmol} / \mathrm{l}$ was present in half of the tubes and incubations were continued at $37^{\circ} \mathrm{C}$. By $10 \mathrm{~min} 52 \pm 6 \%$ of the cell-associated radioactivity had dissociated in the absence of insulin and $60 \pm 5 \%$ in its presence. By $90 \min 87 \pm 7 \%$ had dissociated in the absence of insulin and all in its presence $(n=3)$. This may indicate a slight negative cooperativity [13]. 
Total adipocyte bound fraction $(B / T)$

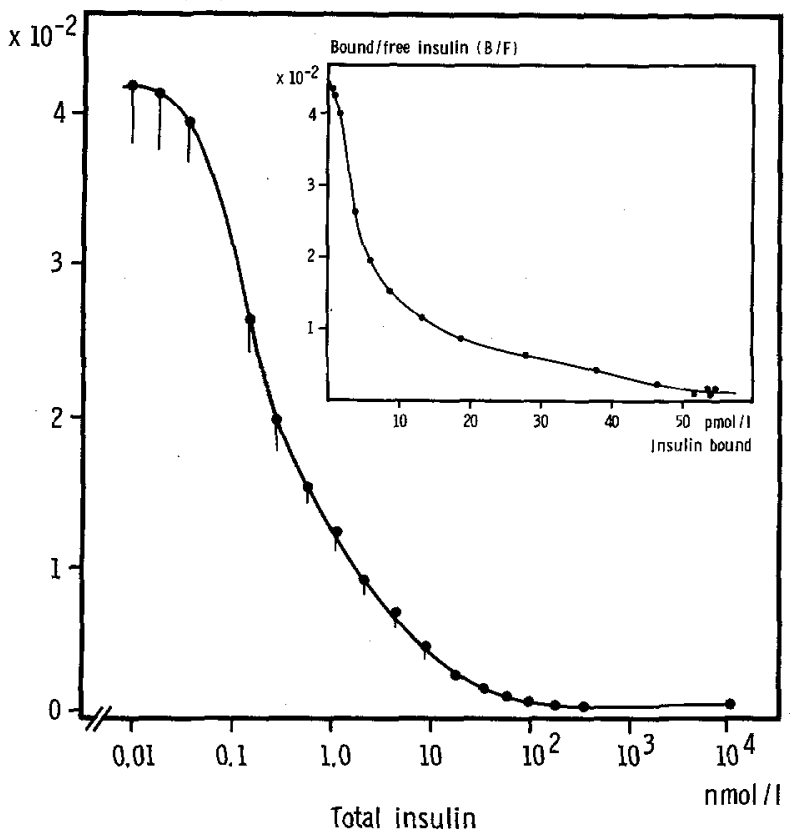

Fig. 4. ${ }^{125} \mathrm{I}$-insulin binding to adipocytes as a function of total insulin concentration. Adipocytes at a final volume fraction of 0.10 (mean cell diameter: $72 \pm 11 \mu \mathrm{m}$ ) were incubated at $37^{\circ} \mathrm{C}$ for $60 \mathrm{~min}$ with tracer iodoinsulin $(10 \mathrm{pmol} / \mathrm{l})$ and increasing amounts of unlabelled insulin. The corresponding Scatchard plot is given in the inset. Mean values \pm 1 SEM obtained in four individual experiments

\section{Insulin Degradation}

Figure $5 \mathrm{~A}$ shows the gel filtration profile of radioactive material extracted from fat cells incubated with $140 \mathrm{pmol} / \mathrm{l}$ iodoinsulin for $1 \mathrm{~h}$. Ninety-five per cent of the radioactivity eluted as the ${ }^{125} \mathrm{I}$-insulin preparation whereas about $5 \%$ eluted with the same $\mathrm{K}_{\mathrm{av}}$ as iodotyrosine. In five individual experiments the amount of iodotyrosine in cells was $7 \pm 3 \%$ of total cell-associated radioactivity.

An insignificant (about 1\%) degradation of insulin was found in the incubation medium after incubation of adipocytes for $1 \mathrm{~h}$ (cf. legend to Fig. 3).

${ }^{125} \mathrm{I}$-insulin bound to adipocytes was allowed to dissociate into a washout buffer containing $10 \mu \mathrm{mol} / 1$ unlabelled insulin which totally inhibited insulin degradation in the medium. After dissociation for one hour, the TCA-soluble component was $10 \pm 4 \%$ of the total radioactivity $(\mathrm{n}=5)$. Similar experiments $(n=5)$ were performed without unlabelled insulin in the buffer. After dissociation for one hour $11 \pm 3 \%$ of the total radioactivity was soluble in TCA confirming the absence of significant extracellular degradation of tracer insulin. The dissociated radioactive material in presence of unlabelled insulin

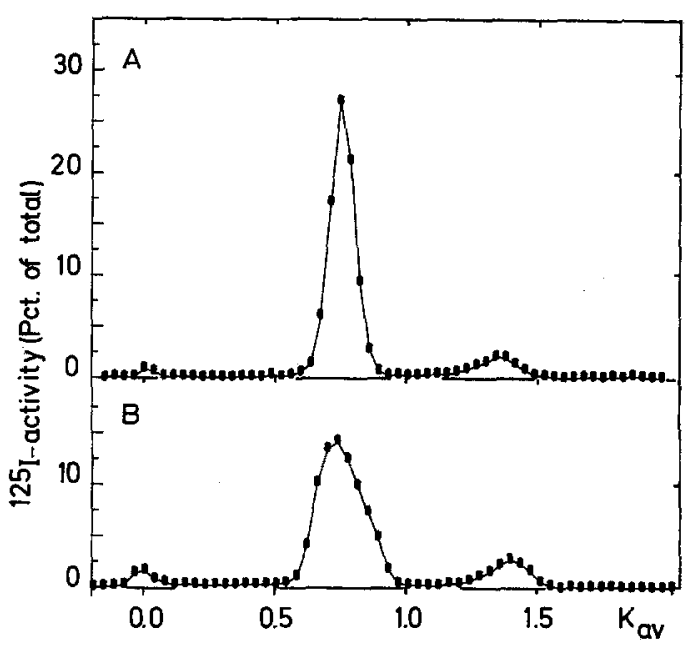

Fig. 5. Panel A. Nature of ${ }^{125}$ I-activity associated with human adipocytes. Human adipocytes (at a final volume fraction of 0.10 ) were incubated at $37^{\circ} \mathrm{C}$ in the presence of $140 \mathrm{pmol} / 1$ of ${ }^{125} \mathrm{I}$ insulin. After $60 \mathrm{~min}$ incubation the cells were separated from the medium in a $4{ }^{\circ} \mathrm{C}$-room as described in Materials and Methods and the cell pellet was immediately transferred to ice-cold $6 \mathrm{~mol} / \mathrm{l}$ urea in $3 \mathrm{~mol} / \mathrm{l}$ acetic acid. This extract was chromatographed on a column $(1.5 \times 90 \mathrm{~cm})$ of Sephadex G-50 Fine eluted with $1 \mathrm{mg} / \mathrm{ml}$ of albumin in $0.5 \mathrm{~mol} / 1$ of acetic acid. Iodoinsulin elutes at $\mathrm{K}_{\mathrm{av}} 0.7$; monoidotyrosine at $\mathrm{K}_{\mathrm{av}} 1.4$ in this system [6].

Panel B. Nature of ${ }^{125}$ I-activity dissociated from human adipocytes. Human adipocytes were incubated as described in A. The cells were isolated, resuspended in buffer containing $10 \mu \mathrm{mol} / \mathrm{l}$ of unlabelled insulin, and allowed to dissociate at $37^{\circ} \mathrm{C}$ for $60 \mathrm{~min}$. The cell-free medium was chromatographed as in $\mathrm{A}$

was chromatographed. As shown in Fig. 5B the radioactivity appeared in three peaks. The first peak corresponded to the void volume (about $4 \%$ ), the second peak co-eluted with iodoinsulin (about $82 \%$ ) and the third peak co-eluted with monoiodotyrosine (about 14\%). In five individual studies iodotyrosine comprised $12 \pm 6 \%$ of total dissociated radioactivity.

In three separate experiments, the fractional degradation of receptor bound insulin at insulin tracer concentration was independent of $\mathrm{pH}$ in the $\mathrm{pH}$ range 6.5 to 8.0 whereas a decline occurred at higher $\mathrm{pH}$ values (data not shown).

\section{Discussion}

\section{Adipocyte Insulin Binding}

Unlike the findings in other cells [14], the $\mathrm{pH}$ optimum for ${ }^{125} \mathrm{I}$-insulin binding to human adipocytes was at a physiological $\mathrm{pH}$. Steady-state of binding at $37^{\circ} \mathrm{C}$ ( $\mathrm{pH} 7.4$ ) could be maintained for $2 \mathrm{~h}$. This finding is in contrast to the results by Olefsky et al. [1] who were unable to establish steady-state binding at $37^{\circ} \mathrm{C}$, presumably due to cell traumatization. In 
the present study the use of a rapid wash with a large dilution before recovery of adipocyte bound insulin made the nonspecific binding negligible. The nonspecific binding is thought to represent loose adsorption of iodoinsulin to adipocytes since the distribution space for L-glucose was ten times lower than that for nonspecifically bound iodoinsulin. Competition curves were well-defined both at very low and at very high concentrations of insulin. The concentration of unlabelled insulin necessary to reduce the specifically bound fraction of iodoinsulin at insulin tracer concentration by $50 \%$ was about $0.25 \mathrm{nmol} / 1$ at $37^{\circ} \mathrm{C}$. This corresponds well to the value given by Andersen et al. [5] but is much lower than the findings at $24^{\circ} \mathrm{C}$ by Olefsky et al. [1] $(1.5 \mathrm{nmol} / 1)$ and Harrison et al. [3] $(1.3 \mathrm{nmol} / \mathrm{l})$. These discrepancies may in part be explained by our finding that steadystate insulin binding at $20^{\circ} \mathrm{C}$ is not reached until after $90 \mathrm{~min}$ and the incubations performed by Olefsky et al. [1] and Harrison et al. [3] were confined to 45 and $30 \mathrm{~min}$, respectively. Lockwood et al. [2] incubated human adipocytes with a very high concentration of tracer iodoinsulin $(480 \mathrm{pmol} / 1)$ at $27^{\circ} \mathrm{C}$ for $10 \mathrm{~min}$. Their reported half-maximal displacement constant was $2.2 \mathrm{nmol} / \mathrm{l}$. This high value may be partially explained by the high tracer concentration and the short incubation period. The half-maximal displacement constant of $0.25 \mathrm{nmol} / 1$ in this study of human fat cells is one order of magnitude lower than that reported for rat adipocytes from young animals [15].

\section{Adipocyte Insulin Degradation}

When incubated to steady-state with ${ }^{125} \mathrm{I}$-insulin human adipocytes contained a pool of monoiodotyrosine ranging from 4 to $11 \%$ of the total cell-associated ${ }^{125} \mathrm{I}$-activity. The size of this pool was similar to that found in rat adipocytes [6]. However, in striking contrast to rat adipocytes, in which about half of the receptor-bound insulin is degraded after dissociation at $37^{\circ} \mathrm{C}$ for $1 \mathrm{~h}$ [6], human fat cells seem only to have a limited ability to degrade receptor-bound ${ }^{125}$ I-insulin by a pathway with monoiodotyrosine as the end product. It should be noted that the present iodotyrosine figures should be taken as maximum values since it is difficult to avoid a slight nonspecific degradation of the ${ }^{125}$-iodoinsulin during the recovery procedure. It seems possible, therefore, that receptormediated degradation is in fact absent in human adipocytes isolated from adults with normal body weight.

Acknowledgements. For supply of fat biopsies we are indebted to the staff of the Departments of Surgery, Aarhus Amtssygehus and Aarhus Kommunehospital and the Department of Obstetrics and Gynecology, Aarhus Kommunehospital. T. Skrumsager, L. Busch,
J. Jørgensen and L. Blak are thanked for skillful technical assistance. The study was supported by grants from the Danish Medical Research Council, Landsforeningen for Sukkersyges Fond, Aarhus Universitets Forskningsfond, Novo Fond and Nordisk Insulin Fond.

\section{References}

1. Olefsky JM, Jen P, Reaven GM (1974) Insulin binding to isolated human adipocytes. Diabetes 23: 565-571

2. Lockwood DH, Livingston JN, Amatruda JM (1975) Relation of insulin receptors to insulin resistance. Fed Proc 34: 1564-1569

3. Harrison LC, Martin FIR, Melick RA (1976) Correlation between insulin receptor binding in isolated fat cells and insulin sensitivity in obese human subjects. J Clin Invest 58: 1435-1441

4. Baxter D, Stanton K, Lazarus NR, Keen H (1978) The relation between insulin and adipocyte insulin receptors during treatment of human obesity. Eur J Clin Invest 8: 361-372

5. Andersen O, Gliemann J, Gammeltoft S (1977) Receptor binding and biological effect of insulin in human adipocytes. Diabetologia 13: 589-593

6. Gliemann J, Sonne O (1978) Binding and receptor-mediated degradation of insulin in adipocytes. J Biol Chem 253: $7857-7863$

7. Olefsky JM, Kobayashi M, Chang H (1979) Interactions between insulin and its receptors after the initial binding event. Functional heterogeneity and relationships to insulin degradation. Diabetes 28: 460-471

8. Jørgensen KH, Larsen UD (1979) Preparation of mono- ${ }^{125}$-I(Tyr A 14)-and mono- ${ }^{125}$ I-(Tyr A 19)-insulin. Excerpta Medica, International Congress Series No 481. 10th Congress of the International Diabetes Federation. 275 (A)

9. Geigy scientific tables (1970), 7th edn

10. Lorch E, Rentsch G (1969) A simple method for staining and counting isolated adipose tissue fat cells. Diabetologia 5: 356-357

11. Sjöström L, Björntorp P, Vrana J (1971) Microscopic fat cell size measurements on frozen-cut adipose tissue in comparison with automatic determinations of ossium fixed fat cells. J Lipid Res 12: $521-530$

12. Gliemann J, Sonne O, Linde S, Hansen B (1979) Biological potency and binding affinity of monoiodoinsulin with iodine in tyrosine $\mathrm{A}_{14}$ or tyrosine $\mathrm{A}_{19}$. Biochem Biophys Res Commun 87: 1183-1190

13. De Meyts P, Roth J, Neville DM Jr, Gavin JR III, Leisniak MA (1973) Insulin interactions with its receptors: Experimental evidence for negative cooperativity. Biochem Biophys Res Commun 55: 154-161

14. Kahn CR (1975) Membrane receptors for polypeptide hormones. In: Korn ED (ed.) Methods in membrane biology, Vol 3. Plenum Publishing Cooperation, New York, pp 81-146

15. Gammeltoft S, Gliemann J (1973) Binding and degradation of ${ }^{125}$ I-labelled insulin by isolated rat fat cells. Biochim Biophys Acta 320: $16-32$

Received: 15 September 1980

and in revised form: 13 October 1980

Dr. Oluf Pedersen

Medical Department III

County Hospital

Tage Hansensgade

DK-8000 Aarhus C

Denmark 